\title{
APLIKASI RASIONAL EMOTIF TERAPI DALAM MEMPERBAIKI PERILAKU MEMBOLOS SISWA
}

\author{
Isop Syafe'i \\ Fakultas Psikologi UIN Sunan Gunung Djati Bandung, Jl. A.H Nasution No. 105 Bandung \\ email: isop.syafei@gmail.com
}

\begin{abstract}
Abstrak
Pendidikan sekarang dihadapkan pada berbagai persoalan yang mengindikasikan adanya perilaku salah suai (malladjusment) pada siswa. Berbagai perilaku malladjusment pada siswa tersebut, merentang dari mulai yang dikategorikan ringan sampai kategori berat, seperti membolos, tawuran, penodongan, pergaulan bebas atau melakukan hubungan seks sebelum nikah, sampai pada mengkonsumsi narkoba dan zat adiktif lainnya (NAZA). Konseling merupakan proses hubungan antara Konselor dengan konseli yang sifatnya membantu konseli dalam mengatasi masalah hidupnya untuk menemukan perilaku yang sesuai dengan aturan dimasyarakat. Albert Ellis mencentuskan teori Rasional Emotif Terapi (RET) yang berasumsi bahwa manusia dilahirkan dengan potensi, baik untuk berpikir rasional dan jujur maupun untuk berpikir irasional dan jahat. Manusia memiliki dua kecenderungan yakni kecenderungan yang bersifat positif dan kecenderungan yang bersifat negatif. Teori RET dengan analisa ABCD-nya akan membantu konselor untuk memahami persoalan klien secara holistik. Untuk memahami permasalahan yang dialami klien, konselor tidak langsung memperbaiki masalahnya, tetapi mencoba mendalami faktor-faktor yang menimbulkan munculnya permasalahan dan sekaligus mereduksi keyakinan-keyakinan irasional pada diri klien.
\end{abstract}

Kata kunci : pendidikan, konseling, perilaku siswa

Abstract

Today, education face many kind of problems that indicate student maladjustment behavior. All sorts of students maladjustment behavior stretch from the lower level to the higher level. For example; cut class, engage in the gang fight, hold-up, free sex and consume the narcotics. Counseling is the process of connection between counselor and counselee that help the counselee solve the problem to find the behavior that conform the rule of the society. Albert Ellis sparked the theory of rational emotive therapy that give the assumption that human had brought the potential to think rationally, honest, and think irrationally and bad. Human has two tendencies, they are positive and negative tendencies.The rational emotive therapy using $A B C D$ analysis can help the counselor to understand the client's problem holistically.

Key words : education, counseling and student's behavior 


\section{PENDAHULUAN}

Di tengah pembangunan pendidikan yang berorientasi pada peningkatan mutu, maka di sisi lain dunia pendidikan dihadapkan pada berbagai persoalan yang mengindikasikan adanya perilaku salah suai (malladjusment) pada siswa. Berbagai perilaku malladjusment pada siswa tersebut, merentang dari mulai yang dikategorikan ringan sampai kategori berat, seperti membolos, tawuran, penodongan, pergaulan bebas atau melakukan hubungan seks sebelum nikah, sampai pada mengkonsumsi narkoba dan zat adiktif lainnya (NAZA).

Adanya fenomena tersebut, merupakan indikasi bahwa pembentukan pribadi dan pengembangan potensi anak didik dalam prakteknya tidak cukup dengan menggunakan pendekatan instruksional, tetapi memerlukan intervensi pendidikan yang menyentuh aspek-aspek psikologis, yang dalam hal ini adalah layanan bimbingan dan konseling. Orientasi dari intervensi bimbingan dan konseling ini, mengedepankan prinsip pembelajaran pada klien dengan menyentuh aspek-aspek psikologis, seperti motivasi, emosi, minat, dan aspek lainnya. Oleh karena itu, peran dari seorang konselor harus mampu memerankan dirinya sebagai "Psychoeducator".

Konseling merupakan satu bentuk hubungan yang bersifat membantu, yakni interaksi antara konselor dengan konseli sebagai satu kondisi yang membuat konseli terbantu dalam mencapai perubahan yang lebih baik. Dalam hal ini, Nelson (1982) yang dikutip Moh. Surya (1998: 1) mengemukakan ada empat alasan bahwa konseling merupakan proses psikologis, yaitu: (1) Dilihat dari tujuannya, rumusan tujuan konseling itu berupa pernyataan yang menggambarkan segi-segi psikologis (perilaku) dalam diri klien, (2) Dilihat dari prosesnya, seluruh proses konseling merupakan proses kegiatan yang bersifat psikologis, (3) Dilihat dari teori dan konsep, konseling bertolak dari teoriteori atau konsep-konsep psikologi, (4) Dilihat dari riset, hampir semua penelitian dalam bidang konseling mempunyai singgungan dengan penelitian dalam bidang psikologi.

Dalam praktek konseling, berbagai tokoh atau pakar konseling mengemukakan berbagai kerangka berpikir dalam proses membantu klien. Masing-masing teori konseling memiliki kekuatan dan kelemahan, dan dalam hal ini yang perlu dipertimbangkan oleh kon- selor atau petugas bimbingan di sekolah adalah dimilikinya kemampuan untuk menganalisis sifat atau jenis permasalahan yang dihadapi klien untuk kemudian dipertimbangkan teori konseling mana yang tepat untuk digunakan.

Berangkat dari pemikiran tersebut, teori konseling yang akan dibahas dalam makalah ini berangkat dair pemikiran yang disumbangkan oleh Albert Ellis yang dikenal dengan sebutan "Rasional Emotif Terapi". Dalam pembahasannya, difokuskan pada analisis tentang "Aplikasi Rasional Emotif Terapi dalam Membantu Memperbaiki Perilaku Membolos pada Siswa SMU".

\section{Pandangan Tentang Sifat Manusia}

Rasional Emotif Terapi (RET) berasumsi bahwa manusia dilahirkan dengan potensi, baik untuk berpikir rasional dan jujur maupun untuk berpikir irasional dan jahat. Manusia memiliki dua kecenderungan yakni kecenderungan yang bersifat positif dan kecenderungan yang bersifat negatif. Kecenderungan positif seperti kecenderungan untuk memelihara diri, berbahagia, berpikir dan mengatakan, mencintai, bergabung dengan orang lain serta tumbuh dan mengaktualisasikan diri. Kecenderungan negatif seperti menghancurkan diri, menghindari pemikiran, berlambat-lambat, menyesali kesalahan secara tak berkesudahan, irasional, intoleransi, perfeksionisme dan mencela diri, serta menghindari pertumbuhan dan aktualisasi diri. Manusiapun cenderung untuk terpaku pada pola tingkah laku lama yang disfungsional dan mencari berbagai cara untuk terlibat dalam sabotase diri.

Dalam pandangan RET, manusia memiliki sumber atau tenaga yang tak terhingga bagi aktualisasi potensi diri dan bisa mengubah ketentuan-ketentuan pribadi dan masyarakatnya. Dalam diri manusia ada kecenderunga untuk mengaktualisasikan dirinya, dan jika terpenuhi keinginannya tersebut, maka manusia akan mempersalahkan dirinya sendiri ataupun orang lain. Manusia berpikir, beremosi dan bertindak secara simultan, dalam pengertian bahwa jarang manusia beremosi tanpa berpikir, sebab perasaan-perasaan biasanya dicetuskan oleh persepsi atas suatu situasi yang spesifik. Manusia bukanlah makhluk yang sepenuhnya ditentukan secara biologis dan didorong oleh nalurinaluri. Tetapi menurut RET, manusia adalah individu unik dan memiliki kekuatan untuk 
memahami keterbatasan - keterbatasan, untuk mengubah pandangan dan nilai dasar yang telah diintroyeksikannya secara tidak kritis pada masa kanak-kanak, dan untuk menolak kecenderunagn menolak diri sendiri. Manusia memiliki kesanggupan untuk mengkonfrontasikan sistem-sistem nilainya sendiri dan mereindoktrinasi diri dengan keyakinan-keyakinan, gagasan-gagasan, dan nilai-nilai yang berbeda. Akibatnya manusia akan bertingkah laku yang berbeda dengan cara bertingkah laku di masa lampau.

\section{Teori Kepribadian}

Neurosis yang didefinisikan sebagai "berfikir dan bertingkah laku irasional" adalah suatu keadaan alami yang pada taraf tertentu menimpa manusia. Keadaan ini berakar pada kenyataan bahwa manusia dan hidup dengan manusia-manusia lain dalam masyarakat. Psikopatologi pada mulanya dipelajari dan diperhebat oleh timbunan keyakinan-keyakinan irasional yang berasal dari orang-orang yang berpengaruh selama masa kanak-kanak. Emosi adalah produk pemikiran manusia, dan jika pikiran manusia buruk tentang sesuatu, maka ia pun akan merasakan sesuatu itu sebagai hal yang buruk.

Dalam pandangan RET, bahwa menyalahkan adalah inti sebagian besar gangguan emosional. Oleh karena itu, jika konselor ingin menymbuhkan orang neurotik atau psikopatik, konselor harus menghentikan penyalahan diri dan penyalahan terhadap orang lain yang ada pada orang tersebut. Dalam hal ini klien harus belajar untuk menerima dirinya sendiri dengan segala kekurangannya.

\section{Teori A-B-C tentang Kepribadian}

Teori A-B-C (Antedence-Believe-Consequence) tentang kepribadian sangatlah penting bagi teori dan praktek RET. A adalah keberadaan suatu fakta, suatu peristiwa, tingkah laku, atau sikap seseorang. B adalah keyakinan individu tentang $\mathrm{A}$, yang menjadi penyebab $\mathrm{C}$, yakni reaksi emosional. $\mathrm{C}$ adalah konsekuensi atau reaksi emosional seseorang; reaksi ini bisa layak dan tidak bisa layak. Misalnya, seorang siswa mengalami depresi karena tidak lulus memasuki PTN, buka ketidaklulusan memasuki PTN itu sendiri yang menjadi penyebab timbulnya reaksi depresif, me- lainkan keyakinan (Believe) siswa itu sendiri tentang ketidaklulusan memasuki PTN seabgai sebuah kegagalan, penolakan, atau kehilangan kesempatan untuk belajar di perguruan tinggi.

Ellis, menandaskan bahwa karena manusia memiliki kesanggupan untuk berpikir, maka manusia mampu melatih dirinya sendiri untuk mengubah atau menghapus keyakinankeyakinan yang menyabotase diri sendiri. Untuk dapat memahami dan mengkonfrontasikan sistem keyakinan diperlukan disiplin diri, berpikir, dan belajar. RET juga berasumsi bahwa karena keyakinan-keyakinan dan nilai-nilai irasional orang-orang berhubungan secara kausal dengan gangguan emosional dari tingkah lakunya, maka cara yang paling efisien untuk membantu orang tersebut dalam membuat perubahan dalam pribadinya adalah mengkonfrontasikan mereka secara langsung dengan filsafat hidup mereka sendiri. Dengan demikian, RET mengkonfrontasikan para klien dengan keyakinan irasionalnya serta menyerang, menantang, mempertanyakan dan membahas keyakinan yang irasional.

Setelah A-B-C, menyusul D = membahas. Pada dasarnya $\mathrm{D}$ adalah penerapan metode ilmiah untuk membantu para klien menantang keyakinannya yang irasional yang telah mengakibatkan gangguan-gangguan emosi dan tingkah laku. Dalam pendekatan ini, prinsip-prinsip logika bisa diajarkan untuk menghilangkan keyakinan yang irasional pada diri klien.

\section{Tujuan Konseling}

Tujuan utama dari konseling menurut pandangan RET adalah meminimalkan (mengurangi) pandangan yang mengalahkan diri klien dan membantu diri klien untuk memperoleh keyakinan hidup yang lebih realistik. RET juga mendorong kepada klien untuk mereevaluasi keyakinan hidup yang telah diyakininya. Ringkasnya, proses konseling terdiri atas penyembuhan irasionalitas dengan rasionalitas.

\section{Fungsi dan Peran Konselor}

Ada beberapa langkah yang harus dijalankan oleh konselor dalam pandangan RET, adalah sebagai berikut : (1) Menunjukkan kepada klien bahwa masalah yang dihadapinya berkaitan dengan keyakinan-keyakinan irasionalnya, menunjukkan bagaimana klien me- 
ngembangkan nilai-nilai dan sikap-sikapnya dan menunjukkan secara kognitif tentang pikiran dan tindakan yang logis, rasional dan normatif, (2) Membawa klien ke tarap kesadaran dengan menunjukkan bahwa klien sekarang mempertahankan gangguan-gangguan emosional untuk tetap aktif dengan terus menerus berpikir secara tidak logis dan dengan mengulang kalimat-kalimat yang mengalahkan diri dan yang memperkuat pengaruh masa kanak-kanak, (3) Berusaha agar klien mem-perbaiki pikiran-pikirannya dan meninggalkan gagasan-gagasan irasionalnya. RET berasumsi bahwa keyakinan-keyakinan yang tidak logis itu berakar dalam sehingga biasanya klien tidak bersedia mengubahnya sendiri.

Perlu dipahami bahwa RET adalah proses edukatif, dimana tugas utama konselor adalah membelajarkan klien tentang cara-cara memahami dan mengubah diri.

\section{Pengalaman Klien dalam Konseling}

Konseling dalam pandangan RET adalah suatu proses reedukatif di mana klien belajar cara menerapkan pikiran logis pada pemecahan masalah. Konseling menitikberatkan pengalaman-pengalaman di sini dan sekarang, dan kemampuan klien untuk mengubah pola-pola berpikir dan beremosi yang diperolehnya pada masa kanak-kanak. Pertanyaan-pertanyaan seperti kapan, mengapa, dan bagaimana klien memperoleh keyakinan yang irasional adalah pertanyaan-pertanyaan sekunder dalam konseling, dan yang lebih penting adalah bagaimana agar klien bisa menjadi sadar atas pesanpesan yang mengalahkan diri dan agar klien menantangnya.

Pengalaman utama klien dalam konse-ling adalah mencapai pemahaman. RET ber-asumsi bahwa pencapaian pemahaman emosional (emosional insight) oleh klien atas sum-bersumber gangguan yang dialaminya adalah bagian yang sangat penting dari proses konseling.

\section{Hubungan Antara Konselor dengan Klien}

Dalam pandangan RET, hubungan pribadi antara konselor dengan klien yang hangat atau mendalam merupakan kondisi yang diperlukan dan memadai bagi proses konseling, dan yang lebih penting bahwa hubungan yang baik antara konselor dengan klien merupakan sesuatu yang sangat diharapkan.

\section{Penerapan Rasional Emotif Terapi dalam Konseling}

RET memberikan keleluasaan kepada konselor untuk menjadi eklektik. Sebagian besar sistem konseling mengandalkan suatu kondisi tunggal yang diperlukan bagi pengubahan kepribadian. RET menandaskan bahwa orangorang bisa mengalami perubahan melalui banyak jalan yang berbeda seperti memiliki pengalaman hidup yang berarti, belajar tentang pengalaman orang lain, memasuki hubungan dengan konselor, menonton film, mendengarkan rekaman, mempraktekkan pekerjaan rumah yang spesifik, melibatkan diri proses konseling dalam jarak jauh.

Teknik RET yang esensial adalah mengajar secara aktif-direktif. Segera, setelah proses konseling dimulai, konselor memainkan peran sebagai pengajar yang aktif untuk mereduksi klien. Lebih dari itu, RET adalah suatu proses didaktik dan karenanya menekankan metodemetode kognitif. Konselor dalam proses konseling cenderung lebih aktif dibandingkan dengan klien. Dalam awal konseling, konselor bisa mengkonfrontasikan kliennya dengan pembuktian atas pemikiran dan tingkah lakunya yang irasional. Tipe klien yang ditangani dengan pendekatan RET mencakup siswa yang mengalami kecemasan yang sedang, yang mengalami masalah perkawinan, yang mengalami gangguan seksual, yang mengalami gangguan kepribadian neurotik dan para remaja nakal, dewasa kriminal dan sebagainya.

\section{PEMBAHASAN}

Sebagaimana telah disinggung dalam sebelumnya, bahwa Rasional Emotif Terapi, merupakan teknik konseling yang mengedepankan prinsip pembelajaran pada klien dengan mengkonfrontasikan keyakinan-keyakinan irasional untuk kemudian dimilikinya keyakinan, pemikiran, dna tindakan yang rasional. Dari pernyataan tersebut dapa dipahami dua kata kunci dalam RET, yakni 1) konseling sebagai proses pembelajaran klien, dan 2) konseling sebagai proses untuk mengkonfrontasikan keyakinan irasional menjadi keyakinan rasional pada diri individu.

Atas pemikiran tersebut, aplikasi teori RET untuk memperbaiki perilaku malladjusment pada siswa SMU memiliki dasar konseptual yang relevan dengan setting masalah, 
yakni klien yang berstatus sebagai pelajar, sehingga konseling dengan mengedepankan pola pembelajaran akan lebih memungkinkan untuk digunakan karena sesuai dengan perkembangan atau posisi siswa SMU dan kedua, substansi masalah yang dihadapi klien adalah malladjusment, merupakan salah satu bidang garapan dari Rasional Emotif Terapi (RET).

Bentuk perilaku malladjusment yang akan dibahas dalam konteks ini adalah Perilaku Membolos pada Siswa SMU. Aplikasi dari RET untuk jenis perilaku malladjusment dimaksud, disajikan dalam pembahasan berikut.

\section{Analisis Teori A-B-C-D}

Teori ABC dalam RET merupakan cara untuk memahami permasalahan yang dihadapi oleh klien. Dalam memahami perilaku membolos pada siswa, maka dapat diuraikan sebagai berikut:

A (Antecendence $=$ peristiwa yang menyebabkan munculnya perilaku pada klien) adalah upaya untuk memahami mengapa klien menunjukkan perilaku membolos. Dalam hal ini, konselor tidak memposisikan karakter individu klien sebagai sumber utama terjadinya perilaku membolos, tetapi mencoba mengembangkan analisisnya dengan memperhatikan kondisi lingkungan rumah dan sekolah, serta teman sebaya. Dalam hal ini, konselor harus menginventarisir kondisi lingkungan siswa. Misalnya dalam lingkungan kelas, harus dilihat bagaimana kondisi pembelajaran yang diikuti oleh klien, seperti metode belajar yang digunakan guru, dan tugas yang diberikan guru dan sikap klien terhadap pelajaran, apakah berpotensi untuk menyebabkan klien membolos. Lingkungan keluarga klien, perlu dianalisis; apakah orang tua klien mendukung atau menghambat untuk sekolah, bagaimana beban yang dipikul klien di rumah, dan seterusnya, yang pada akhirnya harus sampai pada sebuah kesimpulan, kondisi lingkungan keluarga yang mana yang berpotensi terhadap perilaku membolos klien. Lingkuang pergaulan dengan teman sebaya klien, perlu ditelusuri; misalnya dengan siapa saja klien bergaul, siapa teman dekat klien, kegiatan apa yang dilakukan klien di luar sekolah bersama teman-temanya. Analisis tersebut akan bermuara pada sebuah kesimpulan, kondisi mana dari lingkungan teman sebaya yang berpotensi untuk menimbulkan perilaku membolos pada klien. Dengan demi- kian, pemahaman akan peristiwa yang memunculkan perilaku membolos pada siswa merupakan langkah awal yang dapat dikerjakan konselor dalam teori RET ini. Inti dari tahap ini, perhatian konselor belum menyentuh pada permasalahan perilaku membolos siswa, tetapi berupaya menggali berbagai informasi yang menyebabkan klien berperilaku membolos.

$\mathrm{B}$ (Believe $=$ keyakinan $)$ adalah keyakinan apa yang dimiliki oleh klien sehingga ia terbiasa dengan perilaku membolos. Dalam hal ini, konselor mengadakan dialog dengan klien, bagaimana perasaan dirinya ketika ia membolos dari sekolah, apakah sebagai bentuk penghindaran dari tugas sekolah yang diberikan dari gurunya, membolos terpaksa dilakukan karena bentuk reaksi emosional terhadap kehidupan keluarga yang disharmonis atau sebagai bentuk loyalitas terhadap gang (kelompok bergaul) dengan teman-temannya untuk sama-sama membolos. Pada tahap ini, konselor harus mampu melakukan konfrontasi terhadap keyakinan-keyakinan irasional klien yang menyebabkan ia berperilaku membolos. Keterampilan dalam berargumentasi dengan klien untuk mereduksi keyakinan-keyakinan irasional merupakan keterampilan mendasar bagi seorang konselor.

Guna membantu konselor dalam mengkonfrontasikan keyakinan-keyakinan irasional pada klien yang menyebabkan perilaku membolos tersebut, konselor dapat menggunakan pendekatan eklektik sistematis. Menurut Moh. Surya (1988: 160), model eklektik sistematis mempunyai tiga macam bentuk dasar pengalaman, yakni; 1) perasaannya (dimensi afektifnya), 2) pikiran dan kepercayaannya (dimensi kognitif), dan 3) tindakannya (dimensi perilaku behavioral). Setiap dasar pengalaman itu saling berinteraksi melengkapi dan mempengaruhi emosi dan tindakan klien akan saling melengkapi dan mempengaruhi dalam suatu keadaan yang berkesinambungan. Sebagaimana disebutkan dalam kerangka konseptual RET di atas, bahwa keyakinan seseorang merupakan penentu utama dalam perasaannya.

Atas dasar pemikiran tersebut, dalam mereduksi perilaku membolos pada klien tersebut, konselor pertama kali harus menghilangkan keyakinan klien bahwa membolos merupakan solusi untuk menghindar dari permasalahan. Setelah klien hilang dalam keyakinan irasionalnya, barulah konselor memupuk keyakinan, sikap, pikiran dan perbuatan yang ra- 
sional, misalnya dengan membolos maka dirinya akan kehilangan kesempatan untuk memperoleh ilmu pengetahuan.

Secara khusus, konselor yang menggunakan pendekatan eklektik sistematis, secara terus menerus akan mengajukan tiga pertanyaan kepada dirinya sendiri selama fase penilaian, sebagai berikut: 1) Masalah-masalah apakah yang paling dominan dalam diri siswa? 2) Dari unsur-unsur internal atau eksternal sistem lingkungan siswa, hal-hal manakah yang merupakan penyebab utama timbulnya masalah? 3) Apakah yang sebaiknya diubah dari sistem lingkungan siswa untuk memecahkan masalah dan membantu perkembangan pribadi?

$\mathrm{C}$ (Consequence $=$ konsekuensi $)$, adalah akibat yang ditimbulkan pada diri klien sebagai produk dari keyakinan irasional yang ada pada dirinya, yang dalam hal ini adalah reaksi emosional diri klien atas A (antecendence) yakni dalam bentuk perilaku membolos. Dalam hal ini harus dipahami oleh konselor bahwa membolos adalah bentuk reaksi emosional klien atas keyakinan-keyakinan irasional dari kondisi lingkungannya. Sehingga, implikasinya bagi proses konseling, tidak hanya terfokus pada upaya memperbaiki perilaku membolos saja pada diri klien, tetapi berupaya memperbaiki sistem lingkungan perkembangan siswa secara kondusif, dan secara simultan mereduksi keyakinan-keyakinan irasional untuk diganti dengan keyakinan-keyakinan rasional, sehingga pada akhirnya potensi yang dimiliki klien dapat diaktualisasikan secara optimal.

Terakhir adalah D (pembahasan), adalah bagaimana konselor menggunakan teknik-teknik ilmiah untuk mereduksi keyakinan-keyakinan irasional pada diri siswa dan sekaligus membangun keyakinan-keyakinan yang rasional. Dalam posisi seperti ini, konselot dapat menggunakan prinsip-prinsip pembelajaran, afektif-direktif, sehingga dapat secara leluasa mengintervensi klien dalam proses perwujudan potensi dirinya secara optimal.

\section{Pendekatan Konseling}

Mencermati jenis permasalahan yang dihadapi klien, maka dalam proses konseling ini dapat menggunakan jenis konseling individual. Yang harus menjadi dasar pemikiran dari konselor, ketika melakukan proses konseling dengan klien adalah yakini bahwa pada diri klien sebenarnya terdapat tenaga atau sumber yang mendorong klien untuk mampu membelajarkan dirinya dalam rangka mereduksi keyakinan-keyakinan irasional dan mengembangkan keyakinan-keyakinan rasional dalam rangka perwujudan potensi dirinya secara optimal.

Untuk mengembangkan pemikiran tersebut, konselor dapat melakukan wawancara secara individu dengan klien, yang isinya mengungkap potensi klien, kekurangan klien dan mengamati lingkungan perkembangan klien (sekolah, rumah dan pergaulan teman sebaya). Denga bermodalkan informasi tentang aspekaspek tersebut, konselor dapat membelajarkan klien untuk dapat mengambil berbagai peluang yang ada dalam dirinya dan lingkungannya ke arah aktualisasi dirinya secara optimal. Aplikasi proses pembelajaran pada diri klien tersebut perlu memperhatikan style of life (gaya hidup) dan style of learning (gaya belajar). Implikasinya, upaya memperbaiki perilaku membolos pada siswa dengan teori RET ini, cenderung relevan dengan menggunakan jenid konseling individual.

\section{SIMPULAN}

Berangkat dari keseluruhan pembahasan dalam makalah ini, dapat dirumuskan beberapa simpulan sebagai berikut :

Pertama, munculnya berbagai fenomena perilaku malladjusment pada sebagian peserta didik dewasa ini, semakin memperkuat asumsi bahwa proses pembentukan pribadi dan pengembangan potensi peserta didik tidak dapat dilakukan dengan pendekatan instruksional semata, tetapi memerlukan intervensi bimbingan konseling sebagai format akumulasi intervensi pendidikan dan psikologis. Hal tersebut berimplikasi bahwa seorang konselor harus mampu memerankan dirinya sebagai Psychoeducator.

Kedua, teori Rasional Emotif Terapi (RET) merupakan salah satu teknik konseling yang dapat digunakan untuk memperbaiki perilaku malladjusment pada diri siswa, seperti halnya perilaku membolos dan perilaku menyimpang lainnya. Asumsi dasar dari teori RET ini adalah memandang bahwa reaksi emosional yang ditunjukkan seseorang adalah sebagai produk dari keyakinan-keyakinan irasionalnya yang menguasai pola pikirnya. Atas dasar tersebut, maka menjadi keterampilan mendasar bagi seorang konselor yang menggunakan teori RET untuk mampu mengkonfrontasikan keyakinan-keyakinan irasional pa- 
da diri klien dan sekaligus membangun keyakinan-keyakinan rasional sebagai instrumen ke arah aktualisasi diri yang optimal.

Ketiga, teori RET dengan analisa ABCD-nya akan membantu konselor untuk memahami persoalan klien secara holistik. Untuk memahami permasalahan yang dialami klien, konselor tidak langsung memperbaiki masalahnya, tetapi mencoba mendalami faktor-faktor yang menimbulkan munculnya permasalahan dan sekaligus mereduksi keyakinan-keyakinan irasional pada diri klien.

Keempat, pendekatan eklektif sistematis dapat digunakan oleh konselor yang menggunakan teori RET dalam konselor sebagai landasan pengungkapan permasalahan klien secara sistematis dan holistik. Pendekatan eklektik ini akan menyentuh paradigma bimbingan ekologis (ekologis guidance), bimbingan perkembangan (development guidance), dan bimbingan komprehensif (comprehensive guiedance) yang dewasa ini merupakan bentuk-bentuk inovasi dalam dunia bimbingan dan konseling.

\section{DAFTAR PUSTAKA}

Blocher, Donald, (1989), The Professional Counselor, Mc. Millan Publishing Co.: New York

Corey, Gerald (1988), Teori dan Praktek Konseling dan Psikoterapi, Bandung, PT. Eresco.

Kardinah dan Tarsono. (2009). Pengantar Teori Konseling dalam Pendidikan. Gunung Djati Press. Bandung

Latipun, (2008). Psikologi Konseling. Malang. UPT UMM.

Moh. Surya, (1988), Eklektik Sistematis; Sebuah Pendekatan Pragmatis Untuk Menterpadukan Metode-metode Konseling (Makalah), Bandung, PPB FIP IKIP. (1994), Konseling Sebagai Satu Pengalaman Baru, Bandung, PPB FIP IKIP.

, (2000), Perilaku Komunikasi Non-Verbal (Materi Perkuliahan Teoriteori Konseling), Bandung, PPS UPI. 